\title{
Primary Clinical Study Sponsor
}

National Cancer Institute

\section{Source}

National Cancer Institute. Primary Clinical Study Sponsor. NCI Thesaurus. Code C70794.

The individual, org anization, group or other legal person taking responsibility for securing the arrangements to initiate and/or manage a study (including arrangements to ensure that the study design meets appropriate standards and to ensure appropriate conduct and reporting). In commercial trials, the primary sponsor is normally the main applicant for regulatory authorization to beg in the study. It may or may not be the main funder. 